\title{
Performance of rabi Sorghum Genotypes (Sorghum bicolor (L) Moench) to Varied Soil Moisture Regimes
}

\author{
Gangadasari Sravana Lakshmi*, B. N. Aravind Kumar, \\ N. G. Hanamaratti and V.S. Kubsad
}

Department of Agronomy and Genetics and Plant breeding, College of Agriculture, University of Agricultural Sciences, Dharwad, Karnataka, India

*Corresponding author

\section{A B S T R A C T}

K e y w o r d s
Rabi sorghum,
Genotypes,
Moisture regimes,
Yield and Yield
parameters

\begin{abstract}
A PVC column experiment was conducted to study the response of rabi sorghum genotypes (Sorghum bicolor (L) Moench) to different soil moisture regimes at AICRP on Sorghum, MARS, Dharwad (Karnataka) during rabi, 2019. The experiment was laid out in Complete Randomised Design with two factors. The Factor 1 consisted of five genotypes and Factor 2 consists of three moisture regimes with fifteen treatment combinations and three replications. CSV 29R in the well watered regime has recorded significantly higher yield $\left(3.43 \mathrm{t} \mathrm{ha}^{-1}\right)$ and yield parameters like panicle length $(16.26 \mathrm{~cm})$, grain weight per ear $(26.45 \mathrm{~g}), 1000$ grain weight $(31.2 \mathrm{~g})$ and $\mathrm{HI}(23.01 \%)$. Moisture stress at 40-60 DAS has caused reduction in yield but the percent reduction was less in SPV $2217(14 \%)$ followed by M 35-1 (15.7\%). Whereas Basavanapada recorded higher percent decrease in yield was recorded (46.6\%). Similarly moisture stress between flowering and dough stage, percent decrease was less in M 35-1(21\%) followed by SPV 2217 (21.5\%). While higher percent decrease was recorded in CSV 29R (34.5\%).
\end{abstract}

\section{Introduction}

Sorghum [Sorghum bicolor (L.) Moench] which is considered as the king of millets is widely grown in more than 105 countries, including India almost in semi-arid tropics (SAT). In India, sorghum is cultivated during kharif (southwest monsoon) and rabi (postmonsoon) season. Rabi sorghum is the major food and fodder crop of water scarcity zones and an important dry land crop grown in the Deccan plateau in the states of Maharashtra (1.10 m ha), Karnataka (0.83 m ha) and
Andhra Pradesh (0.14 m ha) with an annual production of $1.74 \mathrm{~m} \mathrm{t}$ and productivity of $744 \mathrm{~kg} \mathrm{ha}^{-1}$ (Anon., 2019). Erratic, scanty rainfall is the major constraint for sorghum higher production. Though sorghum is an indigenous crop and exceptionally adapted to the dry regions, the productivity is generally less than $1.4 \mathrm{t} \mathrm{ha}^{-1}$ (Anon., 2017). Moisture deficit, the most important abiotic stress and significantly limits crop production globally, particularly in the semiarid tropics.Rabi sorghum being grown under receding soil moisture conditions experiences both the soil 
and atmospheric droughts which is one of the major constraints responsible for destabilizing the productivity. Drought stress affects almost every stage of the plant growth. However, damaging drought effects were more prevalent in sorghum when coinciding with different growth stages such as panicle initiation and anthesis (Sharma and Singh, 2003) which differs from genotype to genotype. However, the percent reduction in the yield depends on the genotype and soil condition (Sinaki et al., 2007).

The genetic mechanisms that regulate the expression of drought tolerance in crop plants are poorly understood as drought tolerance is a complex trait controlled by several genes and depends on the timing and severity of moisture stress. Genetic potential of the genotypes shows considerable difference in the traits like differences in water extraction and the water use pattern before and after anthesis. Selection of the rabi sorghum genotypes with drought adaptable traits is most important factor for increased productivity in moisture limited environments. Hence the present investigation is carried out to with an objective to know the most sensitive stage of water requirement for different genotypes so that the available water can be used effectively for higher productivity.

\section{Materials and Methods}

A PVC column experiment was conducted during rabi 2019-2020 in clay loam soil at AICRP on Sorghum, MARS, University of Agricultural Sciences, Dharwad, which is situated at $15^{\circ} 29^{\prime} \mathrm{N}$ latitude, 74 $59^{\prime}$ E longitudes at an altitude of $689 \mathrm{~m}$ above mean sea level.

PVC tubes of $1 \mathrm{~m}$ length and $15 \mathrm{~cm}$ diameter were cut vertically into two pieces, the cut surface were attached by parcel tape. The bottom of the PVC tubes were capped with polythene sheet and few holes were made to drain out excess water. About $18 \mathrm{~kg}$ of air dried soil was added on each column. The prepared columns were further used for planting sorghum seeds

The experiment was laid out in Factorial CRD with three replications. The experiment consists of 2 factors (5 genotypes and 3 moisture regimes) with 15 treatments. Clay loam soil with neutral $\mathrm{pH}$ (7.2) was used in the experiment. The recommended dose of nitrogen, phosphorous was applied at the rate of 50: $25 \mathrm{~kg} \mathrm{~N}, \mathrm{P}_{2} \mathrm{O}_{5} \mathrm{ha}^{-1}$ in the form of urea and Diammonium phosphate (DAP). Nitrogen was applied in two split doses i.e., 50percent as basal and 50 percent at 30 days after sowing. Diammonium phosphate (DAP) was applied as basal dose. The recommended amount of fertilizer was calculated as per the weight of soil in the column and applied.

The crop was sown on $16^{\text {th }}$ October, 2019 and harvested on $16^{\text {th }}$ February, 2020. The various growth and yield parameters and yield were calculated as per the standard procedure. The data collected on different parameters were subjected to statistical analysis as described by Gomez and Gomez (1984) for better interpretation of results.

\section{Treatment details}

\section{Factor -1: Rabi sorghum genotypes}

$$
\begin{aligned}
& \mathrm{V}_{1}: \text { M 35-1 } \\
& \mathrm{V}_{2}: \text { SPV2217 } \\
& \mathrm{V}_{3}: \text { CSV 29 R } \\
& \mathrm{V}_{4}: \text { CSH 15R } \\
& \mathrm{V}_{5}: \text { Basavanpada }
\end{aligned}
$$

\section{Factor -2: Moisture levels}

$\mathrm{M}_{1}$ : Well watered regime

$\mathrm{M}_{2:}$ Moisture stress at 40-60 days after sowing 


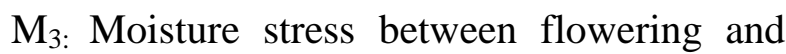
dough stage

\section{Treatment combinations}

The treatment combinations are as follows $\mathrm{T}_{1}$ (M 35-1 with well watered condition), $\mathrm{T}_{2}$ (M35-1 with water stress at 40-60 DAS), $\mathrm{T}_{3}$ (M 35-1 with water stress between flowering and dough stage), $\mathrm{T}_{4}$ (SPV 2217 with well watered condition), $\mathrm{T}_{5}$ (SPV 2217 with water stress at 40-60 DAS), T6 (SPV 2217 with water stress between flowering and dough stage), $\mathrm{T}_{7}$ (CSV 29R with well watered condition), $\mathrm{T}_{8}$ (CSV 29R with water stress at 40-60 DAS), $\mathrm{T}_{9}$ (CSV 29R with water stress between flowering and dough stage), $\mathrm{T}_{10}$ (CSH 15R with well watered condition), $\mathrm{T}_{11}$ (CSH 15R with water stress at 40-60 DAS), $\mathrm{T}_{12}$ (CSH 15R with water stress between flowering and dough stage), $\mathrm{T}_{13}$ (Basavanapada with well watered condition), $\mathrm{T}_{14}$ (Basavanapada with water stress at 40-60 DAS) and $\mathrm{T}_{15}$ (Basavanapada with water stress between flowering and dough stage).

\section{Results and Discussion}

The results obtained from investigation as well as relevant discussion have been summarized below in following heads

\section{Genotypes}

A perusal of data in Table 1 showed that among genotypes, SPV 2217 has recorded higher grain weight per ear and grain yield (2.88 $\left.\mathrm{t} \mathrm{ha}^{-1}\right)$. M 35-1 (2.83 $\left.\mathrm{t} \mathrm{ha}^{-1}\right)$ and CSV 29R (2.79 $\left.\mathrm{t} \mathrm{ha}^{-1}\right)$ were on par with the highest treatment. Similar trend was recorded among genotypes with respect to grain weight per ear, 1000 grain weight and HI. Higher yield recorded in genotypes SPV 2217 and M 35-1 was attributed by higher grain weight per ear and 1000 grain weight $\left[\mathrm{V}_{2}(27.61 \mathrm{~g})\right.$ and 27.03g] respectively. Whereas Basavanapada has recorded lower yield $\left(2.28 \mathrm{t} \mathrm{ha}^{-1}\right)$ and yield parameters among all the five genotypes.

\section{Moisture regimes}

Among the moisture regimes well watered moisture regime has recorded significantly higher grain yield $\left[\mathrm{M}_{1}\left(3.2 \mathrm{t} \mathrm{ha}^{-1}\right)\right]$ and the lower grain yield was recorded by the moisture regime with water stress between flowering and dough stage $\left[\mathrm{M}_{3}\left(2.39 \mathrm{t} \mathrm{ha}^{-1}\right)\right]$

Among the moisture regimes well watered moisture regime has recorded significantly higher panicle length $\left[\mathrm{M}_{1}(15.11 \mathrm{~cm})\right]$ and the moisture regime with water stress between 40-60 DAS has recorded the lower panicle length $\left[\mathrm{M}_{2}(12.95 \mathrm{~cm})\right]$. Higher yield parameters like panicle length, grain weight per ear,1000 grain weight and HI were recorded by the well watered moisture regime and the moisture regime with water stress between flowering and dough stage has recorded the lower yield and yield parameters. These results are in agreement with Jabereldar et al., (2017), who reported that well watered moisture regime has recorded considerably higher yield and yield components than the moisture regime with stress at eight leaf stage.Yield decrease of $28.25 \%$ and $22.5 \%$ was recorded in the moisture regime with water stress between 40-60 DAS $\left[\mathrm{M}_{2}\right]$ and with water stress between flowering and dough stage $\left[\mathrm{M}_{3}\right]$ respectively. It was reported by Assefa (2010) that moisture stress during reproductive stage in sorghum reduces the final grain yield consistently

\section{Interaction effect}

Significant differences were recorded among the interaction effects. Higher grain yield was recorded by the CSV 29R in the well watered moisture regime $\left[\mathrm{V}_{3} \mathrm{M}_{1}\left(3.43 \mathrm{t} \mathrm{ha}^{-1}\right)\right]$ followed by M 35-1 and SPV 2217 in the well watered 
moisture regime $\left[\mathrm{V}_{1} \mathrm{M}_{1}\left(3.23 \mathrm{tha}^{-1}\right)\right.$ and $\mathrm{V}_{2} \mathrm{M}_{1}$ $\left.\left(3.33 \mathrm{t} \mathrm{ha}^{-1}\right)\right]$ which were on par with the highest treatment. Whereas Basavanapada in the moisture regime with water stress between 40-60 DAS $\left[\mathrm{V}_{5} \mathrm{M}_{2}\left(1.58 \mathrm{t} \mathrm{ha}^{-1}\right)\right]$ has registered the lower grain yield among all the treatments. CSV 29 R, M 35-1 and SPV 2217 in the well watered regime has recorded higher yield parameters like grain weight per ear and 1000 grain weight compared to other genotypes in the moisture stressed regimes.

Table.1 Growth, yield and yield parameters of rabi sorghum as influence

by different moisture regimes

\begin{tabular}{|c|c|c|c|c|c|c|}
\hline \multirow[t]{2}{*}{ Treatments } & \multirow{2}{*}{$\begin{array}{c}\text { TDM at } \\
\text { harvest } \\
\left(\text { g plant }^{-1}\right)\end{array}$} & \multicolumn{5}{|c|}{ Yield parameters } \\
\hline & & $\begin{array}{l}\text { Length } \\
\text { of the ear } \\
\text { (cm) }\end{array}$ & $\begin{array}{c}\text { Grain weight } \\
\text { per ear }(g)\end{array}$ & $\begin{array}{l}\text { Grain } \\
\text { yield } \\
\left(\mathrm{t} \mathrm{ha}^{-1}\right)\end{array}$ & $\begin{array}{l}1000 \text { Grain } \\
\text { weight (g) }\end{array}$ & $\begin{array}{c}\text { Harvest Index } \\
(\%)\end{array}$ \\
\hline \multicolumn{7}{|l|}{ Factor -I (Varieties) } \\
\hline$V_{1}-M 35-1$ & 74.64 & 13.54 & 21.83 & 2.83 & 27.03 & 22.63 \\
\hline$V_{2-S P V ~} 2217$ & 74.70 & 14.64 & 22.14 & 2.88 & 27.61 & 22.85 \\
\hline$V_{3^{-}}$CSV 29R & 73.22 & 14.85 & 21.49 & 2.79 & 27.10 & 22.75 \\
\hline$V_{4^{-}}$CSH 15R & 69.26 & 13.84 & 19.70 & 2.56 & 25.73 & 21.91 \\
\hline$V_{5}$ - Basavanapada & 66.91 & 13.38 & 17.57 & 2.28 & 24.54 & 20.33 \\
\hline S.Em. \pm & 0.71 & 0.143 & 0.203 & $\mathbf{0 . 0 3}$ & 0.223 & 0.186 \\
\hline C.D. $(P=0.01)$ & 2.77 & 0.557 & 0.788 & 0.13 & 0.867 & 0.725 \\
\hline \multicolumn{7}{|c|}{ Factor -II (Moisture regimes) } \\
\hline $\mathbf{M}_{1}$ & 81.68 & 15.11 & 24.68 & 3.20 & 29.42 & 23.11 \\
\hline $\mathbf{M}_{2}$ & 73.74 & 12.95 & 18.52 & 2.40 & 26.53 & 19.75 \\
\hline $\mathbf{M}_{3}$ & 59.81 & 14.09 & 18.44 & 2.40 & 23.25 & 23.42 \\
\hline S.Em. \pm & 0.55 & 0.111 & 0.157 & 0.03 & 0.173 & 0.144 \\
\hline C.D. $(P=0.01)$ & 2.14 & 0.432 & 0.610 & 0.10 & 0.672 & 0.562 \\
\hline \multicolumn{7}{|l|}{ Interaction $(\mathbf{V} \times \mathbf{M})$} \\
\hline $\mathbf{V}_{1} \mathbf{M}_{1}$ & 81.50 & 14.45 & 24.92 & 3.23 & 29.30 & 23.40 \\
\hline $\mathbf{V}_{1} \mathbf{M}_{2}$ & 77.48 & 13.12 & 20.96 & 2.72 & 27.17 & 21.29 \\
\hline $\mathbf{V}_{1} \mathbf{M}_{3}$ & 64.95 & 13.06 & 19.62 & 2.55 & 24.62 & 23.20 \\
\hline $\mathbf{V}_{2} \mathbf{M}_{1}$ & 82.30 & 15.53 & 25.63 & 3.33 & 30.10 & 23.74 \\
\hline $\mathbf{V}_{2} \mathbf{M}_{2}$ & 78.29 & 14.26 & 21.78 & 2.83 & 28.15 & 21.76 \\
\hline $\mathbf{V}_{2} M_{3}$ & 63.50 & 14.12 & 19.01 & 2.47 & 24.58 & 23.04 \\
\hline $\mathbf{V}_{3} M_{1}$ & 88.50 & 16.26 & 26.45 & 3.43 & 31.20 & 23.01 \\
\hline $\mathbf{V}_{3} \mathbf{M}_{2}$ & 75.26 & 13.80 & 20.65 & 2.68 & 28.14 & 21.53 \\
\hline $\mathbf{V}_{3} \mathbf{M}_{3}$ & 55.89 & 14.50 & 17.37 & 2.25 & 21.96 & 23.71 \\
\hline $\mathbf{V}_{4} \mathbf{M}_{1}$ & 79.50 & 14.86 & 23.60 & 3.06 & 28.70 & 22.89 \\
\hline $\mathbf{V}_{4} \mathbf{M}_{2}$ & 69.90 & 12.01 & 17.01 & 2.21 & 25.40 & 19.21 \\
\hline $\mathbf{V}_{4} \mathbf{M}_{3}$ & 58.37 & 14.65 & 18.50 & 2.40 & 23.10 & 23.64 \\
\hline $\mathrm{V}_{5} \mathrm{M}_{1}$ & 76.62 & 14.43 & 22.80 & 2.96 & 27.80 & 22.53 \\
\hline $\mathbf{V}_{5} M_{2}$ & 67.77 & 11.57 & 12.19 & 1.58 & 23.80 & 14.95 \\
\hline $\mathrm{V}_{5} \mathbf{M}_{3}$ & 56.33 & 14.13 & 17.71 & 2.31 & 22.01 & 23.50 \\
\hline S.Em. \pm & 1.23 & 0.248 & 0.351 & 0.06 & 0.386 & 0.323 \\
\hline C.D. $(P=0.01)$ & 4.79 & 0.965 & 1.364 & 0.22 & 1.502 & 1.256 \\
\hline
\end{tabular}

Note: $\mathrm{M}_{1}$ - Well watered moisture regime; $\mathrm{M}_{2}$ - Moisture stress between 40-60 DAS; $\mathrm{M}_{3^{-}}$Moisture stress between flowering and dough stage; TDM: Total dry matter 
Decrease in the grain yield and yield parameters was recorded with application of moisture stress in all genotypes, but the percentage decrease varied among genotypes with the timing of occurrence of stress. Large variation in the yield was recorded among the genotypes which varied with time of imposition of moisture stress which might be due to the genetic potential of genotypes to tolerate drought stress and also on the time of occurrence of drought which was also reported by (Craufurd and Peacock, 1993).

When the moisture stress was imposed between 40-60 DAS decrease in the yield and yield parameters was recorded. Supporting evidence was reported by Mutava (2009); Younesi and Moradi (2009) who stated that withholding irrigation at eight-leaf stage decreased grain yield. This decrease might be due to unavailability of water at the time of booting which had its effect on flowering by increasing the degree of floral abortion (Nouri, 2005) reduced the panicle exertion and also the number of the grains to be filled. The genotype with lesser percent decrease in yield[SPV $2217(15.8 \%)]$ was recorded as tolerant to pre-flowering moisture stress and Basavanapada (46.5\% decreease) which has shown larger percent decrease was recorded as the most sensitive one to moisture stress at 40-60 DAS.

Similarly decrease in the yield and yield parameters was recorded when the moisture stress was imposed between flowering and dough stage which might be due to decreased size of grain and hence test weight. Similar results were reported bySaini and Westgate (2000). Higher percent decrease in yield was recorded by CSV 29R (34.3\%) and the lower by M 35-1 (21.2\%) which was attributed by decreased grain weight per ear, and test weight which followed nearly same trend of decrease. This could be due to the susceptibility of CSV 29R to post-flowering water stress and lack of moisture which inhibited the growth of the seed that reduced the size of the seed and panicle and hence yield. Test weight was the most effected yield component due to water stress between flowering and dough stage compared to preflowering stress which might be due to its effect on expansion and development of seed to its full potential which was hindered by lack of moisture. This was similar with findings of Jabereldar et al., (2017).

Thus based on the results, SPV 2217 was recorded tolerant to moisture stress at 40-60 DAS followed by M 35-1 and Basavanapada was more sensitive with higher percent of decrease in yield and yield parameters. Whereas M 35-1 and CSV 29 R were more tolerant and sensitive to stress between flowering and dough stage respectively.

\section{References}

Anonymous, 2017. Area, production and productivity of sorghum in world Food and Agriculture Organization of the United Nations, FAO, http://www.fao.org/faostat/en/\#data/RL

Anonymous, 2019. Area, production and productivity of sorghum in India. http//www.Indiastat.com.

Assefa, Y., Staggenborg, S. A. and Prasad, V. P. V. 2010. Grain sorghum water requirement and responses to drought stress. A review. Crop Manag., 9 (1).

Craufaurd, P. Q. and Peacock, J. M. 1992. Effect of heat and drought stress on sorghum (Sorghum bicolor) grain yield.Exp. Agric.,29: 77-86.

Gomez, K. A. and Gomez, A. A.1984. Statistical procedure for agricultural research. $2{ }^{\mathrm{nd}} \mathrm{Ed}$. Wiley interscience publication, New York, pp. 21-29.

Jabereldar, A. A., Naim, A. M. E., Abdalla, A. A. and Dagash, Y. M. 2017. Effect of water stress on yield and water use 
efficiency of sorghum (Sorghum bicolor L. Moench) in semi-arid environment. Int. J. Agric. and Forestry, 7 (1): 1-6.

Mutava, R., 2009. Characterization of grain sorghum for physiological and yield traits associated with drought tolerance. M. Sc. (Agri.) Thesis, Kansas State Univ., Manhattan, Kansas.

Nouri, R. A. H., 2005. Performance of selected sorghum (Sorghum bicolor L. Moench) genotypes under water stress condition. M. Sc. (Agri.) Thesis, Univ. Khartoum, Sudan.

Saini, H. S., and Westgate, M. E.2000. Reproductive development in grain crops during drought. Adv. Agron., 68: 59-96.

Sharma, A. D. and Singh, P.2003.
Comparative studies on drought induce changes in Peptide poly Cis., Trans. Isomerase's activity in drought tolerance and susceptible cultivars of sorghum bicolor. Curr. Sci., 84(7): 911918.

Sinaki, J. M., Haravan, E. M., Rad, A. H. S., Noormohammadi, G. and Zarei, G.2007. The effects of water deficit during growth stages of canola (Brassica napus L.). AmericanEurasian J. Agri. Environ. Sci., 2: 417422.

Younesi, O. and Moradi, A.2009. The effect of water limitation in the field on sorghum seed germination and vigor. Australian J. Basic and Appl. Sci., 3 (2): 1156- 1159.

\section{How to cite this article:}

Gangadasari Sravana Lakshmi, B. N. Aravind Kumar, N. G. Hanamaratti and Kubsad, V. S. 2020. Performance of rabi Sorghum Genotypes (Sorghum bicolor (L) Moench) to Varied Soil Moisture Regimes. Int.J.Curr.Microbiol.App.Sci. 9(11): 1241-1246. doi: https://doi.org/10.20546/ijcmas.2020.911.146 